\title{
Pengaruh Media Pembelajaran Natural Picture Terhadap Hasil Belajar Siswa Pada Mata Pelajaran IPA
}

\author{
Effect of Learning Media Natural Picture on Student Result On Science \\ Subject
}

\author{
Ruril Rudianto ${ }^{1 *}$, Supiana Dian Nurtjahyani ${ }^{1}$ \\ Program Studi Pendidikan Biologi Universitas PGRI Ronggolawe Tuban Jl. Manunggal 61 Tuban, Jawa Timur, Indonesia \\ *Corresponding author: rurilrudianto@gmail.com
}

\begin{abstract}
Science is a science that learns about life in the world from all aspects. To be able to study these subjects requires a deeper understanding of the material. Application of learning innovations needs to be done to achieve the objectives of science subjects especially by teachers so as to provide hands-on experience for students to acquire innovative learning. Based on the observations at SMP Negeri 1 Bancar known that the results obtained by students less satisfactory. The process of teaching and learning is done by lecture method, when the learning process takes place many students are sleepy and chatting. To improve the learning outcomes in science subjects especially biology required the existence of learning innovation, namely by using Natural Picture learning media. The purpose of this study is to determine whether there is an influence of Natural Picture learning media on student learning outcomes in science biology subjects in SMP Negeri 1 bancar. The type of research used is Quasi Eksperimen. This research was conducted at SMP Negeri 1 Bancar with research sample that is student of class VII A which amounted to 32 students as experiment class and student of class VII E which amounted to 32 students as control class. The research design used was Pre-Test research design - Post-Test Control Group Design. Based on the results of data analysis of learning results, the average value in the experimental class given treatment using Natural Picture learning media is higher than the control class using the lecture method. The experiment class is 87.12 and the control class is 74.37. In the hypothesis test the Sig value. (2tailed) of 0.000 , when compared with $\alpha 0.05$ then $\mathrm{Sig}<\alpha$ then $\mathrm{H} 0$ is rejected and $\mathrm{H} 1$ accepted. Thus, it can be concluded that there is a difference in mean values of experimental class learning outcomes and control classes. That is, there is the effect of learning media Natural Picture on student learning outcomes.
\end{abstract}

Keywords Learning Media, Natural Picture, Student, Learning Outcomes, Science

\section{PENDAHULUAN}

Mata pelajaran IPA bertujuan agar siswa memiliki kemampuan mengembangkan tentang berbagai macam segala sesuatu yang terjadi di alam, konsep dan prinsip IPA yang bermanfaat dan dapat diterapkan dalam kehidupan sehari-hari sehingga terjadi peningkatan pengetahuan, konsep, dan keterampilan IPA sebagai dasar untuk melanjutkan ke jenjang yang lebih tinggi (BSNP, 2006). Penerapan strategi pembelajaran yang tepat perlu dilakukan untuk mencapai tujuan mata pelajaran IPA terutama oleh guru sehingga dapat memberikan pengalaman langsung agar siswa memperoleh pembelajaran yang inovatif. Melalui proses pembelajaran yang inovatif memberikan pengalaman-pengalaman yang bermakna dan diselenggarakan secara interaktif, aspiratif, dan menyenangkan dapat memotivasi siswa berperan aktif serta memberikan ruang yang cukup bagi prakarsa, kreativitas, dan kemandirian. Selain itu dalam proses pembelajaran harus sesuai dengan minat, bakat, perkembangan fisik serta psikologis siswa. Karena seorang siswa akan belajar lebih baik, bermutu dan lebih bermakna apabila anak mengalami apa yang dipelajari dan bukan sekedar mengetahuinya (Depdiknas, 2002).

Hasil belajar merupakan gambaran tentang bagaimana siswa memahami materi yang disampaikan oleh guru. Hasil belajar merupakan output nilai yang berbentuk angka atau huruf yang didapat siswa setelah menerima materi pembelajaran melalui sebuah tes atau ujian yang disampaikan guru. Dari hasil belajar tersebut guru dapat menerima informasi seberapa jauh siswa memahami materi yang dipelajari. Keberhasilan siswa dalam mencapai hasil belajar pada setiap siswa berbeda-beda. Ada beberapa faktor yang mempengaruhi keberhasilan siswa dalam mencapai hasil belajar dikelompokkan menjadi dua yaitu faktor internal dan faktor eksternal. Faktor internal adalah 
segala faktor yang berasal dari dalam diri siswa, diantaranya tingkat intelegensi, minat, motivasi dan sebagainya. Sedangkan faktor eksternal adalah segala faktor dari luar diri siswa, diantaranya lingkungan keluarga, masyarakat, pergaulan, fasilitas belajar, keadaan sosial ekonomi keluaraga dan sebagainya.

Berdasarkan hasil pengamatan peneliti di SMP Negeri 1 Bancar semester genap tahun pelajaran 2017/2018, diketahui bahwa hasil belajar yang diperoleh siswa kurang memuaskan. Proses belajar mengajar di kelas dilakukan dengan metode mengajar ceramah, ketika proses pembelajaran tersebut berlangsung, banyak siswa yang mengantuk dan mengobrol. Rasa ingin tahu siswa tidak terbangun, kemandirian dalam kegiatan pembelajaran dan ketekunan yang dimiliki belum terlihat. Selain itu hanya ada beberapa siswa yang aktif di kelas, mereka mengajukan beberapa pertanyaan yang berkaitan dengan materi yang telah diajarkan, namun masih banyak siswa yang hanya menjadi pendengar dan tergolong pasif di kelas. Siswa tidak termotivasi dalam melakukan kegiatan pembelajaran. Jika hal demikian didiamkan saja oleh guru dan tidak diupayakan adanya perbaikan maka tujuan kegiatan pembelajaran tentu tidak akan dapat tercapai dengan maksimal.Untuk memperbaiki hasil belajar pada mata pelajaran IPA khususnya Biologi diperlukan adanya inovasi pembelajaran, salah satunya menggunakan media pembelajaran Natural Picture.

Media pembelajaran Natural Picture adalah salah satu media pembelajaran yang dapat mengasah pemahaman dan pengusaan konsep. Media pembelajaran Natural Picture disajikan dalam bentuk gambar, konten gambar didesain menarik dan inovatif dari fakta yang terdapat di alam serta terdapat kesimpulan dan penjelasan-penjelasan yang terdapat pada gambar sesuai materi dalam mata pelajaran IPA Biologi yang di diskusikan secara berkelompok. Media pembelajaran Natural Picture mengajarkan kepada siswa interaksi kelompok dan proses diskusi yang baik. Untuk menarik perhatian dan rasa ingin tahu siswa, media pembelajaran Natural Picture di kemas dalam amplop desain batik, dan setiap materi antara amplop satu dengan yang lain saling terkait dan logis yang diharapkan memunculkan minat dan motivasi siswa untuk mengikuti proses pembelajaran. Penggunaan media pembelajaran dalam proses belajar mengajar dapat menimbulkan rasa ingin tahu dan minat dalam diri individu, membangkitkan motivasi dan memberi stimulus dalam mengikuti kegiatan belajar dan bahkan membawa pengaruh positif pada psikologis siswa (Azhar Arsyad, 2013). Melalui media pembelajaran ini juga dapat membantu siswa untuk lebih mudah dalam memahami konsep materi pada mata pelajaraan IPA Biologi.

Tujuan penelitian ini adalah untuk mengetahui apakah ada pengaruh media pembelajaran Natural Picture terhadap hasil belajar siswa pada mata pelajaran IPA Biologi pokok bahasan Pemanasan Global.

\section{METODE PENELITIAN}

Penelitian ini merupakan penelitian quasi eksperimen. Penelitian quasi eksperimen adalah suatu cara untuk menggali hubungan sebab akibat antara 2 faktor yang sengaja dimunculkan oleh peneliti dengan menyisihkan atau mengurangi faktor-faktor yang dapat mengganggu. Eksperimen selalu dilakukan dengan maksud untuk melihat akibat dari suatu perlakuan yaitu dengan sengaja mengusahakan timbulnya variabel-variabel. Perlakuan pada penelitian ini yaitu dengan diberikan media pembelajaran Natural Picture dan selanjutnya dikontrol untuk dilihat pengaruhnya terhadap hasil belajar siswa. Rancangan yang digunakan dalam penelitian ini adalah desain eksperimen dengan kelompok kontrol (Pre-Test - Post-Test control group desain) (Sugiyono, 2010).

Penelitian ini dilakukan di SMP Negeri 1 Bancar Kabupaten Tuban, Tahun pelajaran 2017/2018.Penelitian ini dilaksanakan pada bulan Maret sampai dengan bulan April 2018. Populasi dalam penelitian ini adalah siswa kelas VII SMP Negeri 1 Bancar Kabupaten Tuban, Tahun pelajaran 2017/2018. Sampel dalam penelitian ini adalah 2 kelas yang diambil dengan menggunakan teknik random acak. Diperoleh kelas VII E sebagai kelas kontrol yang menggunakan metode ceramah dan kelas VII A sebagai kelas eksperimen yang menggunakan media pembelajaran Natural Picture. Kelas VII E sebagai kelas kontrol berjumlah 32 siswa yang diberikan perlakuan model pembelajaran ceramah. Kelas eksperimen yakni VII A berjumlah 32 siswa yang menggunakan media pembelajaran Natural Picture.

Jenis data dalam penelitian ini adalah data kuantitatif, yaitu data yang dapat diukur secara langsung dan dapat dinilai dengan angka. Data kuantitatif diperoleh dari nilai Pre-Test dan PostTest.Sumber data dalam penelitian ini adalah data primer. Data diperoleh dari sumbernya secara langsung. Data primer dalam hal ini adalah hasil belajar siswa SMP Negeri 1 Bancar. Hasil belajar ini meliputi ranah kognitif yang diukur menggunakan Pre-Test dan Post-Test.

Dalam penelitian ini menggunakan beberapa metode pengambilan data, diantaranya sebagai berikut:

1. Teknik Tes

Tes adalah barisan pertanyaan, latihan atau perangkat yang digunakan untuk mengukur keterampilan, pengetahuan, kemahiran intelektual, kemampuan atau potensi yang dimiliki oleh beberapa individu (Arikunto, 2013). Dalam penelitian ini dilakukan 2 kali tes, yaitu Pre-Test dan Post-Test. Tes diberikan pada siswa kelas kontrol yang menggunakan metoda ceramah dan kelas eksperimen yang menggunakan media Natural Picture, dari data inilah yang dijadikan acuan untuk menarik kesimpulan akhir. Tes yang diberikan pada penelitian ini adalah tes tulis yang menggunakan soal essay, sebanyak 5 soal Pre-Test dan 5 soal pada Post-Test.

2. Teknik Dokumentasi 
Teknik dokumentasi digunakan untuk mendapatkan dokumentasi berupa foto siswa selama melakukan kegiatan pembelajaran dan daftar nama siswa yang menjadi sampel penelitian pada kelas eksperimen dan kelas kontrol.

Instrumen penelitian yang digunakan untuk mengetahui hasil belajar siswa adalah tes tulis yang akan diberikan pada kelas eksperimen dan kelas kontrol. Dimana soal tersebut adalah sama, baik bentuk dan bobot soalnya. Selanjutnya untuk soal tes terlebih dahulu dilakukan dahulu uji validitas dan realibilitas. Sebuah instrumen dinyatakan valid apabila dapat memenuhi syarat yang diinginkan serta dapat menampilkan data dan variable yang di sedang teliti secara akurat. Untuk menguji validitas empiris instrumen, peneliti mencoba instrumen tersebut pada sasaran penelitian. Untuk mengetahui data ini diperlukan teknik uji validitas yaitu dengan menggunakan rumus korelasi product moment (Sugiyono, 2010), rumus yang digunakan sebagai berikut:

$$
r_{x y}=\frac{N \sum X Y-\left(\sum X\right)\left(\sum Y\right)}{\sqrt{\left\{N \sum X^{2}-\left(\sum X\right)^{2}\right\}\left\{N \sum Y^{2}-\left(\sum Y\right)^{2}\right\}}}
$$

Keterangan :

$$
\begin{array}{ll}
\text { rxy } & =\text { Koefisiensi antara variable } \mathrm{x} \text { dan } \mathrm{y} \\
\mathrm{N} & =\text { Banyaknya siswa } \\
\mathrm{X} & =\text { Skor tiap butir soal } \\
\mathrm{Y} & =\text { Skor total yang diperoleh siswa } \\
\Sigma \mathrm{x} & =\text { Jumlah skor butir soal }
\end{array}
$$

Untuk menentukan tingkat (derajat) validitas evaluasi dapat digunakan kriteria sebagai berikut :

$0,80 \leq \mathrm{r} \leq 1,00$ : validitas sangat tinggi

$0,60 \leq \mathrm{r} \leq 0,80$ : validitas tinggi

$0,40 \leq \mathrm{r} \leq 0,60$ : validitas sedang

$0,20 \leq \mathrm{r} \leq 0,40$ : validitas rendah

$0,00 \leq \mathrm{r} \leq 0,20$ : validitas sangat rendah

Adapun cara yang digunakan oleh peneliti untuk menguji validitas soal yaitu dengan memberikan soal sebagai instrumen kelas uji coba. Hasil perhitungan kemudian dikonsultasikan product moment dengan signifikansi 5\%, jika rxy $>\mathrm{r}$ tabel maka soal tersebut adalah valid, dan jika rxy $<\mathrm{r}$ tabel maka item tes tidak valid. Untuk menghitung tingkat validitas peneliti menggunakan bantuan aplikasi komputer yaitu program SPSS 19 dengan menggunakan corelate bivariate.

Tahap selanjutnya adalah uji reliabilitas. Menurut Suharsimi Arikunto (2013) mengemukakan bahwa reliabilitas berhubungan dengan masalah kepercayaan. Suatu tes dapat dikatakan mempunyai tingkat kepercayaan yang tinggi jika tes tersebut dapat memberikan hasil yang tetap. Target bahwa suatu instrumen evaluasi harus valid menyangkut harapan yang diperolehnya data yang nyata, sesuai dengan fakta yang terjadi. Jika validitas mencakup dengan keselarasan objek yang tidak lain adalah tidak melenceng dari kenyataan, artinya bahwa data tersebut benar. Untuk menguji reliabilitas tes prestasi belajar dalam hal ini digunakan rumus KR-20 sebagai berikut:

$$
r_{11}=\left(\frac{n}{n-1}\right)\left(\frac{S^{2}-\sum p q}{S^{2}}\right)
$$

Keterangan:

r11 = Reliabilitas tes secara keseluruhan

$\mathrm{p} \quad=$ Proporsi subjek yang menjawab item dengan benar

$\mathrm{q}=$ Proporsi subjek yang menjawab item dengan salah $(\mathrm{q}=1-\mathrm{p})$

$\sum \mathrm{pq} \quad=$ Jumlah hasil perkalian $\mathrm{p}$ dan $\mathrm{q}$

$\mathrm{n} \quad=$ Banyak item

$\mathrm{S}^{2} \quad=$ Standar deviasi dari tes /varian total (Arikunto, 2013)

Peneliti mengukur realibilitas soal dengan cara bantuan komputer program SPSS 19. Dimana hasil dari reliabilitas soal dapat diketahui melalui Output Reliabity Statistics dengan standart reliable 0,6. Jika reliable kurang dari 0,6 menandakan suatu reliabilitas kurang baik, sedangkan jika 0,6 maka reliabilitas dapat diterima atau dikatakan baik. Intrumen dalam penelitian ini sudah teruji baik validitas dan reliabilitasnya dengan menggunakan program SPSS 19.

Peosedur penelitian yang dilakukan terdiri atas dua tahapan yaitu yang pertama adalah tahap persiapan. Tahap persiapan dilakukan sebelum peneliti melakukan penelitian dengan melakukan beberapa persiapan antara lain:

A. Pengajuan surat izin observasi dan surat izin penelitian

B. Melakukan observasi, kemudian menentukan populasi dan sampel yang akan digunakan dalam penelitian.

C. Menyiapkan silabus, rencana pelaksanaan pembelajaran (RPP) sesuai dengan materi pemanasan global dan menyiapkan soal-soal yang akan diujikan.

Tahap yang kedua adalah tahap pelaksanaan. Tahap ini peneliti melakukan pembelajaran model ceramah pada kelas kontrol dan media Natural Picture pada kelas eksperimen. Kedua kelas melaksanakan pembelajaran dengan tiga tahap yaitu tes awal, pembelajaran dan tes akhir. Tes awal dilakukan untuk mengetahui kemampuan dasar dari siswa sebelum pembelajaran, dan tes akhir dialakukan untuk mengetahui hasil belajar siswa setelah mengikuti pembelajaran. Alokasi waktu yang digunakan untuk kedua kelas relative sama yaitu 1 kali pertemuan tes awal (Pre-Test), 2 kali pertemuan untuk pembelajaran, dan 1 kali pertemuan untuk tes akhir (Post-tes).

A. Tahap proses pembelajaran pada kelas eksperimen

1) Dilakukan Pre-Test pada kelas eksperimen untuk mengetahui kondisi awal siswa.

2) Dilakukan penerapan media pembelajaran Natural Picture dengan tahapan yang mana mempunyai mekanisme sebagai berikut:

a) Siswa dibagi menadi beberapa kelompok dengan jumlah anggota perkelompok adalah 4-5 siswa dan setiap kelompok memiliki ketua.

b) Ketua kelompok mengambil media Natural Picture yang sudah di siapkan.

c) Setelah itu siswa belajar dalam kelompok dengan menggunakan media Natural Picture dan setiap 
kelompok menyiapkan pertanyaan untuk di ajukan kepada kelompok lain.

3) Dilakukan Post-Test untuk mengetahui hasil belajar siswa setelah proses pembelajaran.

B. Tahap pembelajaran pada kelas Kontrol

1) Dilakukan Pre-test untuk mengetahui kondisi awal siswa

2) Menerapkan pelajaran dengan metode ceramah pada materi pemanasan global.

3) Dilakukan Post-Test untuk mengetahui hasil belajar siswa setelah pembelajaran.

Analisis data dalam penelitian ini menggunakan uji t, yang sebelumnya diadakan uji normalitas dan uji homogenitas varian antara kelas eksperimen dan kelas kontrol. Uji normalitas dilakukan untuk mengetahui apakah data yang diperoleh tersebut normal atau tidak. Untuk memperoleh perhitungan dengan cepat peneliti menggunakan bantuan komputer melalui program SPSS 19 dengan menggunakan uji KolmogorovSmirnov. Uji homogenitas dilakukan untuk mengetahui tentang adanya keasamaan varian antara kedua kelas penelitian. Untuk menguji kehomogenan peneliti menggunakan bantuan komputer melalui program SPSS 19. Uji hipotesis data hasil belajar siswa dianalisis dengan menggunakan uji t. Penelitian ini menggunakan dua sampel terpisah dan tidak ada kaitannya, sehingga uji $\mathrm{t}$ yang digunakan dalam penelitian ini adalah independent samples t-test. Analisis data uji indepentdent samples t-test dua pihak, perhitungan dilakukan dengan bantuan komputer program SPSS 19.

\section{HASIL DAN PEMBAHASAN}

Hasil penelitian eksperimen meliputi data hasil belajar siswa masing-masing kelas, yaitu kelas eksperimen dan kelas kontrol. Pre-Test yang diberikan di awal untuk mengetahui kemampuan siswa sebelum pembelajaran. Post-Test yang diberikan di akhir pembelajaran setelah mendapatkan perlakuan dari peneliti digunakan sebagai data hasil belajar.

\section{Data Hasil Penelititan}

Berdasarkan data nilai tes awal dan hasil belajar siswa kelas eksperimen dan kelas kontrol didapatkan ratarata pada masing-masing kelas seperti pada tabel dan grafik sebagai berikut:

\section{Nilai Pre-Test}

Nilai rata-rata Pre-Test dapat dilihat pada tabel 1 sebagai berikut:

Tabel 1. Rata-rata Nilai Pre-Test

\begin{tabular}{cc}
\hline Kelas & Nilai Rata-rata Pre-Test \\
\hline Eksperimen & 65,63 \\
\hline Kontrol & 59,50 \\
\hline
\end{tabular}

Dari tabel 1. diperoleh hasil nilai rata-rata PreTest pada kelas eksperimen sebesar 65,63 sedangkan nilai rata-rata Pre-Test kelas kontrol sebesar 59,50. Data dari hasil perhitungan nilai Pre-Test kelas eksperimen dan kelas kontrol untuk lebih jelasnya dapat dilihat pada grafik gambar 1 .

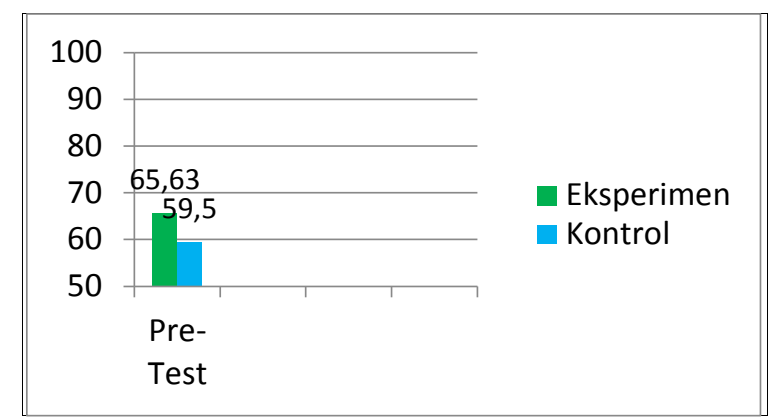

Gambar 1. Nilai Rata-rata Pre-Test

\section{Nilai Post-Test}

Nilai rata-rata Post-Test dapat dilihat pada tabel 2 sebagai berikut:

Tabel 2. Nilai Rata-rata Post-Test

\begin{tabular}{cc}
\hline Kelas & Nilai Rata-rata Post-Test \\
\hline Eksperimen & 87,12 \\
\hline Kontrol & 74,37 \\
\hline
\end{tabular}

Dari tabel 2. diperoleh hasil nilai rata-rata PostTest pada kelas eksperimen sebesar 87,12 sedangkan nilai rata-rata Pre-Test kelas kontrol sebesar 74,37. Data dari hasil perhitungan nilai Post-Test kelas eksperimen dan kelas kontrol untuk lebih jelasnya dapat dilihat pada grafik gambar 2 .

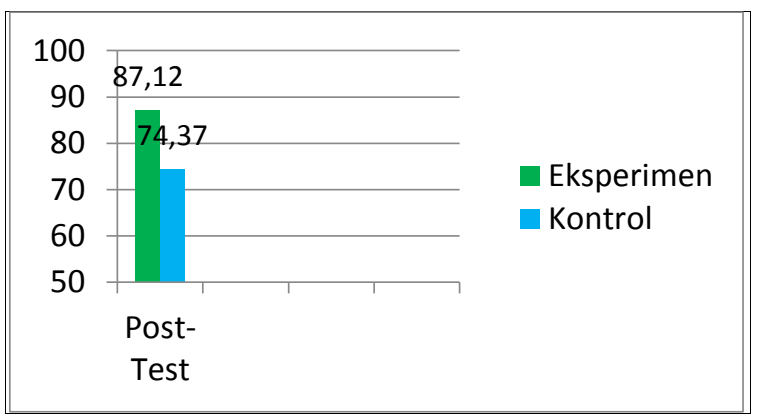

Gambar 2. Nilai Rata-rata Post-Test

\section{Analisis Data Hasil Belajar Siswa}

Analisis data pada penelitian ini dengan menggunakan uji t yang menggunakan bantuan komputer program SPSS 19. Syarat untuk uji t harus terlebih dahulu melakukan uji normalitas dan homogenitas. Data yang diperoleh dari nilai Post-Test digunakan untuk mengidentifikasi normalitas dan homogenitas kemampuan siswa kelas VII A dan VII E SMP Negeri 1 Bancar Kecamatan Bancar Kabupaten Tuban Tahun Pelajaran 2017/2018 yang berperan sebagai obyek penelitian. Setelah soal diujikan kepada kelas 
eksperimen dan kelas kontrol maka didapatkan hasil belajar dan hasil belajar tersebut di uji normalitas. Uji Normalitas data digunakan untuk mengetahui apakah data tersebut berdistribusi normal atau tidak. Pengujian normalitas menggunakan bantuan komputer program SPSS 19. Berdasarkan pada uji normalitas baik dari uji Kolmogorov-Smirnov dan uji Shapiro-Wilk, nilai Sig untuk kedua data $>0,05$. Sehingga dapat disimpulkan bahwa data dari kedua obyek penelitian berdistribusi normal. Dari uji kolmogorov-Smirnov Sig kelas eksperimen adalah 0,200 . Jika dibandingkan dengan $\alpha 0,05$ maka Sig $>\alpha$ $(0,200>0,05)$ dan Sig kelas kontrol adalah 0,157. Jika dibandingakan dengan $\alpha 0,05$ maka Sig $>\alpha(0,157>$ $0,05)$.

Dari uji Shapiro-Wilk Sig kelas eksperimen adalah 0,159 . Jika dibandingkan dengan $\alpha 0,05$ maka Sig $>\alpha(0,159>0,05)$ dan Sig kelas kontrol adalah 0,199 . Jika dibandingkan dengan $\alpha 0,05$ maka Sig $>\alpha$ $(0,199>0,05)$.

Berdasarkan kriteria pengujian yaitu jika signifikansi $>0,05$, maka $\mathrm{H}_{0}$ diterima yang berarti kedua data tersebut berdistribusi normal. Dari perhitungan tersebut, baik dari uji KolmogorovSmirnov maupun Shapiro-Wilk dapat disimpulkan bahwa kedua data tersebut berdistribusi normal.

Uji homogenitas data digunakan untuk mengetahui apakah data tersebut memiliki varian yang sama atau tidak. Uji homogenitas data dilakukan dengan SPSS 19. Data yang digunakan untuk menguji homogenitas adalah nilai Post-Test kelas eksperimen dan kelas kontrol. Hasil uji homogenitas, signifikansi didapat 0,368 . karena nilai signifikansi $>0,05(0,368$ $>0,05)$, maka $\mathrm{H}_{0}$ diterima. Jadi dapat disimpulkan bahwa kelompok data nilai Post-Test antara kelas eksperimen dan kontrol memiliki varian yang sama.. Data yang dianalisis untuk uji $\mathrm{t}$ adalah nilai Post-Test yaitu nilai yang diperoleh setelah kelas eksperimen dan kelas kontrol mendapatkan perlakuan dari peneliti.

\subsubsection{Uji Hipotesis}

Uji hipotesis yang digunakan adalah uji $t$ menggunakan dua sampel terpisah dan tidak saling terkait yang disebut independent samples t-test dengan menggunakan SPSS 19. Uji hipotesis ini digunakan untuk mengetahui apakah ada perbedaan hasil belajar yang diperoleh antara kelompok eksperimen dan kelompok kontrol dilihat dari nilai rata-rata. Langkahlangkah uji $t$ adalah sebagai berikut:

a. Penyusunan Hipotesis:

$\mathrm{H}_{0}$ : Tidak ada perbedaan hasil belajar yang diperoleh antara kelas eksperimen dan kelas kontrol.

$\mathrm{H}_{1}$ : Ada perbedaan hasil belajar yang diperoleh antara kelas eksperimen dan kelas kontrol.

b. Pengambilan Keputusan:

Jika signifikansi $>0,05$, maka $\mathrm{H}_{0}$ diterima dan $\mathrm{H}_{1}$ ditolak.

Jika signifikansi $<0,05$, maka $\mathrm{H}_{0}$ ditolak dan $\mathrm{H}_{1}$ diterima.

Hasil perhitungan dari uji t dengan menggunakan SPSS 19 dapat dilihat pada tabel 3 sebagai berikut:

Tabel 3. Uji Hipotesis (Uji t)

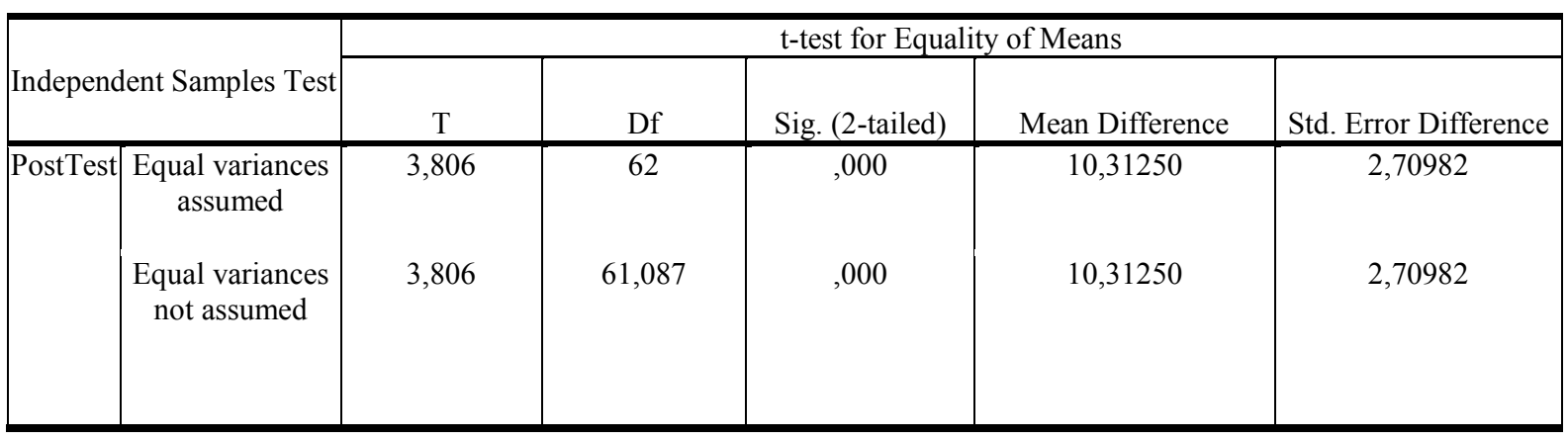

Berdasarkan tabel 3 dapat dilihat bahwa hasil uji $\mathrm{t}$ pada kolom Sig. (2-tailed) nilainya 0,000. Jika dibandingkan dengan $\alpha 0,05$ maka Sig $<\alpha$ maka $\mathrm{H}_{0}$ ditolak dan $\mathrm{H}_{1}$ diterima. Jadi, dapat disimpulkan bahwa ada perbedaan rata-rata nilai Post-Test kelas eksperimen dan kelas kontrol. Artinya, ada pengaruh media pembelajaran Natural Picture terhadap hasil belajar siswa.

\subsubsection{Pembahasan}

Data hasil belajar pada penelitian ini diperoleh dari nilai Post-Test yang diberikan di akhir pembelajaran pada masing-masing kelas. Berdasarkan data hasil belajar siswa, diketahui bahwa nilai rata-rata nilai Post-Test pada kelas eksperimen 87,12 dan kelas kontrol 74,37. Maka dapat diketahui bahwa hasil belajar siswa yang menggunakan media pembelajaran Natural Picture lebih baik dari pada hasil belajar siswa dengan metode ceramah. Hasil dari penelitian ini didukung oleh hasil penelitian Roliza Yulisa (2014) yang membuktikan bahwa dengan digunakannya media gambar hasil belajar kelas yang diajarkan dengan media gambar lebih baik dari pada hasil belajar kelas yang tanpa menggunakan media gambar. 
Berdasarkan tabel 3 hasil uji t data nilai Post-Test diketahui nilai hitung Sig. (2-tailed) sebesar 0,000 dan nilai $\alpha$ sebesar 0,05 . Oleh karena itu, $\operatorname{Sig}<\alpha$, maka dapat disimpulkan bahwa kedua data tersebut memiliki perbedaan secara signifikansi dikarenakan ada perbedaan rata-rata nilai Post-Test kelas eksperimen dan kelas kontrol. Hasil analisis data pada penelitian ini diperkuat dari hasil penelitian Juanita Siska (2006) yaitu dengan pemanfaatan media gambar dengan metode ceramah terbukti terdapat perbedaan yang signifikan antara hasil belajar biologi kelas eksperimen yang menerapkan media pembelajaran gambar dengan hasil belajar biologi kelas kontrol yang menggunakan metode ceramah. Maka dapat disimpulkan bahwa ada pengaruh media Natural Picture terhadap hasil belajar siswa pada mata pelajaran IPA biologi pada materi pemanasan global.

Media pembelajaran Natural Picture merupakan media pembelajaran yang berdampak positif dalam meningkatkan hasil belajar siswa, sebab dalam pembelajaran ini siswa bekerja sama dalam kelompok untuk menyelesaikan tugas yang diberikan oleh guru sehingga mereka lebih berani untuk aktif berdiskusi, bertukar pendapat dengan teman sekelompok, dan menjawab pertanyaan yang diberikan oleh kelompok lain. Pengunaan media pembelajaran Natural Picture juga mempermudah siswa memahami materi karena pada setiap gambar terdapat penjelasan dan rangkuman untuk dipelajari siswa dalam kelompok. Penelitian yang dilakukan di SMP Negeri 1 Bancar tahun pelajaran 2017/2018 pada kelas eksperimen yaitu kelas VII A dengan menggunakan media pembelajaran Natural Picture, siswa lebih aktif berdiskusi bersama kelompok masing-masing, mudah memahami materi dan hasil belajar lebih baik dari pada kelas kontrol yaitu kelas VII E yang menggunakan metode ceramah.

Berdasarkan hasil analisis data dan hasil belajar siswa serta uraian pembahasan hasil penelitian tersebut, telah terbukti bahwa terdapat perbedaan yang signifikan antara kelas eksperimen yang menggunakan media pembelajaran Natural Picture dan kelas kontrol yang menggunakan metode ceramah. Hal yang menyebabkan kelas yang menggunakan media pembelajaran Natural Picture memiliki rata-rata lebih tinggi dibandingkan dengan kelas yang menggunakan metode ceramah dikarenakan media pembelajaran Natural Picture membawa siswa aktif didalam pembelajaran. Meskipun diberikan materi yang sama dengan waktu yang sama pula, namun didalam media pembelajaran Natural Picture siswa dapat memahami materi dengan mudah karena terdapat keterangan pada gambar yang dapat memperkuat pemahaman terhadap materi yang disampaikan. Sedangkan pada metode ceramah siswa hanya terpaku pada penjelasan guru dan siswa kurang aktif dalam pembelajaran.

\section{SIMPULAN}

Berdasarkan hasil penelitian dan pembahasan yang telah dilakukan, maka dapat ditarik kesimpulan bahwa ada pengaruh media pembelajaran Natural Picture terhadap hasil belajar siswa pada mata pelajaran IPA. Pengaruh tersebut terlihat pada nilai rata-rata hasil belajar kelas eksperimen yang menggunakan media pembelajaran Natural Picture lebih baik dibandingkan dengan kelas kontrol yang menggunakan metode ceramah.

Berdasarkan hasil penelitian yang telah dilakukan, ada beberapa saran yang dikemukakan oleh peneliti yaitu:

1. Bagi Sekolah

Berdasarkan penelitian ini disarankan agar proses belajar mengajar dengan menggunakan media pembelajaran Natural Picture dapat digunakan pada saat pembelajaran di kelas.

2. Bagi Guru

Media pembelajaran Natural Picture dapat digunakan sebagai salah satu alternatif media pembelajaran yang dapat meningkatkan kualitas belajar mengajar khususnya mata pelajaran IPA Biologi.

3. Bagi Peneliti

Hasil penelitian ini dapat dijadikan referensi bagi peneliti selanjutnya, serta dapat diterapakan pada mata pelajaran lainnya.

\section{UCAPAN TERIMA KASIH}

Terima kasih kepada seluruh pihak yang telah membantu jalannya penelitian ini.

\section{DAFTAR PUSTAKA}

Arends, Richard. I. 2008. Belajar Untuk Mengajar. Yogyakarta: Pustaka Pelajar

Arikunto, Suharsimi. 2013. Prosedur Penelitian. Cetakan Ke-15. Jakarta: PT. RinekaCipta.

Arsyad, Azhar. 2013. Media Pembelajaran. Jakarta: PT. Raja Grafindo Persada.

BSNP. 2006. Standar Isi Mata Pelajaran IPA SMP/MTs. Jakarta: BSNP.

Depdiknas. 2002. Ringkasan Kegiatan Belajar Mengajar. Jakarta: Depdiknas.

Dimyati \& Mudjiono. 2006. Belajar dan Pembelajaran. Jakarta: Rineka Cipta

Djamarah, Syaiful. 2003. Psikologi Kependidikan. Bandung: Pt. Remaja Rosda Karya.

Fitriyanti, Wulan. 2016. Pengaruh Model Pembelajaran Visualization Auditory Kinestik (VAK) Terhadap Hasil Belajar Siswa Pada Mata Pelajaran Biologi Kelas VII MTs Salafiyah Plumpang Tahun Ajaran 2015/2016. Skripsi tidak diterbitkan Tuban: Program Sarjana Universitas PGRI Ronggolawe Tuban.

Hakim, Thursan. 2001. Belajar Secara Efektif: Panduan Menemukan Teknik Belajar, Memilih Jurusan, dan Menentukan Cita-cita. Jakarta: Puspa Swara.

Isjoni. 2010. Pembelajaran Kooperatif. Yogyakarta: PustakaBelajar

Kusmana. 2011. Penilaian Otentik. Diakses dari suherliecenter.blogspot.com/2010/07/penilaianotentik.html) pada tanggal 23 Maret 2018.

Muhidin, S.A. 2010. Statistika 2 Pengantar Untuk Penelitian. Bandung: Karya Andhika. 
Muizaddin, R., \& Santoso, B. 2016. Model Pembelajaran Core Sebagai Sarana Dalam Meningkatkan Hasil Belajar Siswa. Jurnal Pendidikan Manajemen Perkantoran. 1 (1) 235-243.

Sagami, G.C. 2012. Keefektifan Media Komik Tanpa Teks Dalam Pembelajaran Menulis Dongeng Pada Siswa Kelas VII SMP Negeri 1 Wates. Yogyakarta: Program Sarjana Universitas Negeri Yogyakarta.

Siska, Juanita. 2006. Pengaruh Pemanfaatan Media Gambar Terhadap Hasil Belajar Biologi Siswa Kelas II SMP YAPIA Ciputat. Jakarta: Program Sarjana UIN Syarif Hidayatullah Jakarta.

Slavin. 2008. Cooperative Learning (Penerjemah Nurulita Yusron). Bandung: Nusa Media

Sugiyono. 2010. Metode Penelitian Pendidikan Pendekatan Kuantitatif, Kualitatif, dan R\&D. Bandung: Alfabeta.

Trianto. 2010. Mendesain Model Pembelajaran Inovatif-Progesif. Jakarta: Kencana Media Group.

Yulisa, R. 2014. Pengaruh Penggunaan Media Gambar Terhadap Hasil Belajar Fisika Pada Siswa Kelas VIII SMP Negeri 1 Baitussalam. Aceh: Program Sarjana Universitas Syiah Kuala.

Wahyuni, T.S. 2015. Pengaruh Model Pembelajaran Team Games Tournament dengan Media Kotak dan Kartu Misterius Terhadap Hasil Belajar Siswa Kelas VII SMP Negeri 1 Bancar Pada Materi Pencemaran Lingkungan. Skripsi tidak diterbitkan. Tuban: Program Sarjana Universitas PGRI Ronggolawe Tuban 